\title{
SOME ASPECTS OF PATIENTS' RIGHTS TO RECEIVE INFORMATION ABOUT THEIR HEALTH STATUS UNDER THE LEGISLATION OF THE RUSSIAN FEDERATION

\author{
Artur I. Khabirov ${ }^{1}$ \\ Gulnara M. Khamitova ${ }^{2}$
}

\begin{abstract}
The relevance of the chosen topic is due to increased legal literacy of patients, the need to respect their rights and increase the responsibility of a medical institution in matters of observing the rights of patients. According to the current legislation of the Russian Federation in the field of health protection, the right of citizens to information about their state of health includes two main components: informing the patient by the attending physician and familiarization with medical documentation.In the first case,

about the established diagnosis; on the prognosis of the development of the disease; methods of medical care related to their risk; possible types of medical intervention, its consequences; the results of medical care. The procedure for familiarizing patients with the originals of medical records is also regulated by law. This study touched upon the implementation of the patient's rights to familiarize themselves with the patient's medical records, obtain copies of medical documents, and introduce electronic medical records.
\end{abstract} the attending physician or medical worker directly providing medical assistance to the citizen is obliged to inform the citizen or his legal representative of the information about the state of his health available in the medical organization, including: information on the results of a medical examination; the presence of disease;

Keywords: medical records, acquaintance with the patient's medical records, obtaining copies, liability, loss of medical documents, rights of patients.

\section{Introduction}

Federal Law of November 21, 2011, No. 323-Ф3 "On the Basics of

\footnotetext{
${ }^{1}$ Kazan Federal University. e-mail: art.khabir@gmail.com. Tel. 8987297161

${ }^{2}$ Kazan State Medical University
} 
Protecting the Health of Citizens in the Russian Federation" (hereinafter the Federal Law "On Protecting the Health of Citizens") [1] regulates the rights and obligations of patients when they receive medical services. Moreover, under the patient, this regulatory legal act refers to an individual who has reached the age of 15 years, who are being provided with medical care or who has applied for medical assistance regardless of whether he has a disease and his condition. One of the elements of a patient's right to information in the field of health is his right to familiarize himself with and receive extracts and copies of his documents stored in a medical institution. Article 22 "Information on the state of health" of this federal law indicates the patient's right to familiarize himself with information about his health in an accessible form for him, including: the results of medical examinations, identified diseases, information about the diagnosis and treatment methods, risks and prognosis of development diseases, types of possible medical intervention. Clauses 4 and 5 of this article establish guarantees for the rights of the patient or his legal representative to obtain the right to access medical documents containing information about his state of health (Clause 4), the ability to receive copies and extracts from medical documents (Clause 5), which are elements of the patient's common right to information.

Similar requirements apply to the official website of a medical organization on the Internet. In accordance with paragraph 7 of Part 1 of Article 71 of the Federal Law "On the Protection of Citizens' Health" [1] it is said that a medical organization is obliged to inform citizens in an accessible form, including using the Internet, about ongoing medical activities and the medical workers of a medical organization, about the level of their education and their qualifications.

\section{Methods}

The study is based on a method of analysis of current Russian legislation and law enforcement practice and existing European (world) standards for legal unification $[2,386]$. The methods of legal modeling and forecasting make it possible to determine the need to amend existing Russian regulations, as well as the need to adjust judicial practice [3]. Thanks to the use of 
modeling and forecasting methods, the consequences of making such changes and adjustments can be ascertained with a sufficient degree of certainty, and it will also be revealed how, ultimately, Russian law enforcement practice will be close to existing European (world) standards [4, 421]. The sociological method allows the assessment of social problems from a legal position, from the perspective of a legislator and law enforcer [5, 651]. The interpretation method complements the comparative legal analysis in the study, allowing you to understand and compare Russian and European (world) legal standards [6, 62]. The use of various methods allowed us to formulate the main theoretical conclusions and make our proposals on the studied sphere of public relations [7, $70 ; 8]$.

\section{Results And Discussion}

The Federal Law of the Russian Federation of November 21, 2011, No. 323-Ф3 "On the Basics of Protecting the Health of Citizens in the Russian Federation" does not define the concept of medical documentation. So what is meant by the term "medical records reflecting the patient's state of health"?
By order of the Ministry of Health of the Russian Federation dated December 15, 2014 No. 834 [9], unified forms of medical documentation used in medical institutions and the procedure for filling them out were approved. This order defines the main document used in clinics of the Russian Federation - the patient's medical record. This order also establishes uniform standards for the registration of records for all outpatient medical institutions, which allow you to create an electronic medical record.

And where should the medical record be kept? At the patient or in the clinic? Order of the Ministry of Health of Russia dated December 15, 2014, No. $834 n$ does not regulate this issue, it only approved unified forms of medical documentation. The letter of the Ministry of Health and Social Development of the Russian Federation dated 04.04.2005 No. 734 / MZ-14 "On the procedure for storing outpatient cards" [10] states that the card is stored in the registry of a medical institution and can only be handed out to the patient with the permission of the head physician medical institution and is stored in the archive for 25 (twenty-five) years after the death of the patient. Thus, the 
ambulatory card is the property of the medical institution, although this order is not normative in nature, but is an explanation and has a by-law nature.

In accordance with paragraph 4 of Article 22 of the Federal Law "On the Protection of Citizens' Health", the Ministry of Health of the Russian Federation developed Order No. 425n of June 29, 2016 "On approving the procedure for familiarizing a patient or his legal representative with medical documentation reflecting a patient's health" [11] . According to this order, medical documentation is provided to the patient or his legal representative on the basis of a written application in a specially equipped room located in a medical facility. This document has removed many of the questions that arise regarding the procedure for familiarizing the patient with medical documentation, but, unfortunately, no regulatory act has been adopted to regulate the procedure for the patient (his representative) to exercise his right to receive documents regarding his state of health, their copies and extracts of them, neither in electronic form, nor on paper. Unresolved is the question of how often the patient can apply for certificates and extracts, whether photo and video recording of medical records is allowed, and many other questions that arise in practice. However, this does not mean that the patient cannot exercise his rights established by law. In the absence of special legal regulation, the general provisions of the Federal Law of May 2, 2006 No. 59-Ф3 On the Procedure for Considering Appeals of Citizens of the Russian Federation [12] apply.

The Federal Law "On the Protection of Citizens' Health" introduced the concept of a "Unified Information System in the Field of Healthcare". Within the framework of this system, information is collected, stored and processed regarding health authorities, private, state, municipal health organizations, as well as other health care activities. In this case, the requirements of the laws on personal data and medical confidentiality must be strictly observed. For the proper implementation of these provisions, it is recommended that medical institutions provide for the development of an internal document (regulation or procedure) of a medical organization that regulates the work of informing patients about their rights and obligations. 
Since the patient's medical record is very important as the main primary document on the patient's health status, the perpetrator, in addition to disciplinary liability, can be brought to administrative or criminal liability for the following articles: deliberate misrepresentation of information in it or destruction (loss) of it: article 13.20. "Violation of the rules of storage, acquisition, accounting or use of archival documents" of the Code of the Russian Federation on Administrative Offenses of December 30, 2001 No. 195-FZ [13]; Article 292 "Official forgery" and Article 325 "Theft or damage to documents, stamps, seals or theft of excise stamps, special stamps or conformity marks" of the Criminal Code of the Russian Federation of June 13, 1996 No. 63-FZ [14].

In the Unified Information System (IGISS), personified accounting is carried out, which is processed data on the persons participating in the provision of medical services and on the persons to whom these services were provided (Article 92 of the Federal Law "On the Protection of Citizens' Health"). Currently, the legislation does not establish the requirement for maintaining medical records in paper form only. Since 2008, the National Standard "Electronic Case History. General Provisions" shall be complied with. GOST R 52636-2006 [15]. However, its use is still voluntary.

Thus, until the norms and legal acts confirming the legal status of the patient's electronic medical card are adopted and enforced, it cannot replace the standard paper form. Unfortunately, cases of loss of a medical record or certificates analyzes, and other medical documents stored in it are not rare due to the fault of medical institutions or the fault of patients.

\section{Summary}

Based on the analysis of the current legislation of the Russian Federation in order to resolve the identified problems, the authors of the article propose to supplement the legal regulation of protecting the health of citizens with the following:

1. In development of paragraph 5 of Article 22 of Federal Law No. 323-Ф3 of 11/21/2011 "On the Basics of Protecting Citizens' Health in the Russian Federation", adopt a regulatory act regulating the procedure 
for exercising a patient's right to gain access to documents reflecting his state of health and to receive copies and extracts from them, as well as access to documents in electronic form.

2. In the development of Article 92 of the Federal Law of November 21, 2011, No. 323-Ф3 "On the Basics of Protecting Citizens' Health in the Russian Federation", to adopt a normative act obliging medical organizations to keep a patient record in electronic form.

\section{Conclusions}

At the conclusion of the study, the authors express confidence that it is the introduction of mandatory electronic medical records that will help to improve the completeness and reliability of information about the health status of patients, facilitate access to its receipt and familiarization, receipt of copies, ensure the safety of information, fully ensure the rights of the patient and medical organization. At the same time, improving the quality of medical records should lead to a reduction in claims from external departmental and extradepartmental control in this area of medical organizations.

\section{Acknowledgments}

The work is performed according to the Russian Government Program of Competitive Growth of Kazan Federal University.

\section{References}

On the Basics of Protecting the Health of Citizens in the Russian Federation: Federal Law of November 21, 2011, No. 323-FZ (as amended and additional) URL: http://www.consultant.ru/document/con s_doc_LAW_162448/ (accessed: 03/13/2019).

Comparative Law. An Introduction to the Comparative Method of Legal Study and Research. By H.C. Gutteridge, K.C., LL.D. (Cambridge Studies in International and Comparative Law, Vol. I.) - London: Cambridge University Press. The Cambridge Law Journal. - 1947. - 9 (3). - pp. 386-387.

William Dale, Legislative Drafting: A New Approach: a Comparative Study of Methods in France, Germany, Sweden, and the United Kingdom. - London: Butterworths, 1977. 341 pages.

Artur I. Khabirov, Gulnara M. Khamitova. On The Issue of the Place of a Loan Commitment in the System of the Russian Law of Obligations // The Journal of Social 
Periódico do Núcleo de Estudos e Pesquisas sobre Gênero e Direito

Centro de Ciências Jurídicas - Universidade Federal da Paraíba

V. 8 - $\mathrm{N}^{\circ} 06$ - Ano 2019 - Special Edition

ISSN | 2179-7137 | http://periodicos.ufpb.br/ojs2/index.php/ged/index
Sciences Research. 2018. - Special Is-sue 5. - pp. 421-424.

Siems, M., \& Mac Síthigh, D. Mapping legal research. The Cam-bridge Law Journal. 2012 - 71 (3). - pp .651-676.

P. Davies. Rectification versus interpretation: the nature and scope of the equitable jurisdiction. - The Cambridge Law Journal. - 2016 .- 75 (1). - pp. 62-85.

Artur Khabirov. On the issue of the consensual construction of a loan agreement // National Academy of Managerial Staff of Culture and Arts Herald. - 2018. - No. 3. pp. 70-73.

A.I. Khabirov, Gulnara M. Khamitova. Legal problems of vaccinal prevention // DILEMAS CONTEMPORANEOSEDUCACION POLIT-ICA Y VALORES. 2018 .- Vol.6, Is .. - Art. No. 39.

On the approval of unified forms of medical documentation used in medical organizations that provide medical care on an outpatient basis and the procedures for filling them out: Order of the Ministry of Health of Russia dated December 15, 2014 No. $834 \mathrm{n}$ (as amended and additional) URL: http://www.consultant.ru/document/cons_d oc_LAW_162448/ (accessed: 05/30/2019). http://www.consultant.ru/document/cons_d oc_LAW_175963/

On the procedure for storing an outpatient card: letter of the Ministry of Health and Social Development of the Russian Federation of 04/04/2005 No. 734 / MZ -14 (as amended and additional) [Electronic resource]. $\quad$ URL: https://www.webapteka.ru/phdocs/doc1082 1.html (accessed: 03/13/2019).

On the approval of the procedure for familiarizing the patient or his legal representative with medical documentation reflecting the patient's health status: Order of the Ministry of Health of Russia of June 29, 2016, No. 425n (as amended and additional) [Digital resource]. URL: http://www.consultant.ru/document/cons_d oc_LAW_162448/

(accessed: 03/13/2019). http://www.consultant.ru/document/cons_d oc_LAW_207065/

On the procedure for considering applications from citizens of the Russian Federation: Federal Law of May 2, 2006 No. 59 - Federal Law (as amended and additional)

URL: http://www.consultant.ru/document/cons_d oc_LAW_59999/ $\% 20$ (дата\%20обращения:\%2013.03.2019\%20г .) $20 \%$ 
Periódico do Núcleo de Estudos e Pesquisas sobre Gênero e Direito

Centro de Ciências Jurídicas - Universidade Federal da Paraíba

V. 8 - N 06 - Ano 2019 - Special Edition

ISSN | 2179-7137 | http://periodicos.ufpb.br/ojs2/index.php/ged/index

Code of the Russian Federation on Administrative Offenses of December 30, 2001 No. 195 - Federal Law (as amended and additional) URL: http://www.consultant.ru/document/cons_d oc_LAW_162448/ (accessed: 03/13/2019). http://www.consultant.ru/document/cons_d oc_LAW_34661/

The Criminal Code of the Russian Federation of June 13, 1996 No. 63 - Federal Law 3 (as amended and additional) URL: http://www.consultant.ru/document/cons_d oc_LAW_10699/ (accessed: 03/13/2019). http://www.consultant.ru/document/con s_doc_LAW_10699/

GOST R 52636-2006 Electronic medical history [Electronic resource]. - URL: http://gostrf.com/normadata/1/4293844/429 3844841.pdf. (Date of treatment: 03/13/2019).

http://gostrf.com/normadata/1/4293844/ 4293844841.pdf 